\title{
Climate Change: The Karst Record (KR5)
}

Chongqing, China, 2-5 June 2008

\section{Hong-Chun LI}

Department of Earth Sciences, National Cheng-Kung University Taiwan, China; hli1960@mail.ncku.edu.tw

A total of 115 delegates from 18 countries attended the $5^{\text {th }}$ international conference of Climate Change: The Karst Record (KR5). The conference, co-sponsored by PAGES, consisted of 76 oral presentations and 29 posters.

Participants presented studies from all over the world and on various climatic parameters, such as temperature, precipitation, monsoon strength and the occurrence of dust storms. Karst (speleothem) records presented at the conference obtained up to seasonal- to decadal-resolution, covered timescales back to Glacial Termination IV (about 340 kyr ago) and were compared to solar forcing and marine and ice core records. In addition to signals of $\delta^{18} \mathrm{O}, \delta^{13} \mathrm{C}$, lamination and trace elements in speleothems, more novel approaches, such as clumped isotopes, biomarkers, rare earth elements and pollen, were presented at the conference and their paleoclimatic interpretation was discussed.

The delegates also discussed problems and suggestions for future work:

(1) Interpretation of speleothem records: Delegates agreed that research should now focus on integrating stalagmite records on a regional climate basis, and on resolving differences between records. Also discussed was the need to untangle $(A)$ the climate signal in stalagmite ${ }^{18} \mathrm{O}$ records-how much is attributed to changes in regional atmospheric patterns (i.e., relationship of monsoon 'strength' with rainfall amount) and how much to global temperature trends, and (B) discrepancies among different stalagmite records from the same region.

(2) Chronology: Although much progress has been made on ICP-MS ${ }^{230} \mathrm{Th} / \mathrm{U}$ dating, we need to continue considering dating uncertainties, especially those relating to "contamination" by initial ${ }^{230} \mathrm{Th}$. Initial ${ }^{230} \mathrm{Th}$ is introduced into karst deposits with detrital material but may also be carried by organics dissolved in the drip water. The resulting stalagmite ${ }^{230} \mathrm{Th} /{ }^{232} \mathrm{Th}$ ratio can therefore be substantially different from the mean crustal value that is often used to correct the dates. It was therefore agreed that more measurements of Th in drip water and modern samples of cave deposits are required to obtain the initial Th ratio. Furthermore, soil from above a cave should be analyzed to get an idea of the soil Th and $U$ isotope ratio. Delegates



115 delegates from 18 countries attended the conference and provided 76 oral presentations and 29 posters.

also felt that greater use should be made of 'isochron' dating. The need to address how to combine analytical error and sampling error when performing U-Th dates was also recognised as an important focus for future research. It was agreed that raw ages should be quoted in publications and errors should also be cited when samples are detritally corrected.

Delegates also discussed the use of $\mathrm{U}-\mathrm{Pb}$ methods to extend the dating of karst records back as far as 10-20 Myrs for comparison with loess and marine records.

(3) Karst Hydrology: The hydrology of the vadose zone is important, as each drip site can be affected by different climatic and environmental conditions, and therefore each stalagmite may record different components of the climate. The need for more work on understanding hydrological processes in the karst system was recognized, for example, using dye tracing from soil to the cave to measure transfer time/ climate signal transfer from the surface to the cave drips.

(4) Other applications: In addition to paleoclimate research, it was agreed that karst records should make a greater contribution to the understanding of natural hazards, environmental issues and ecosystem problems (e.g., karst-desertification).

(5) Data archiving: The importance of adding all data to the World Data Center for Paleoclimatology was recognised by the delegates. This must include archiving of ${ }^{13} \mathrm{C}$ and ${ }^{18} \mathrm{O}$ with the raw chronological data.

(6) Sustainability of sampling stalagmites: Stalagmites are non-renewable resources. It was felt that the community should archive samples for younger generations and help them to continue the karst record series. The delegates recommended that, where possible, coring techniques and/or broken stalagmites should be used.

The next karst record meeting, KR6, will be held at the University of Birmingham, UK in 2011. 